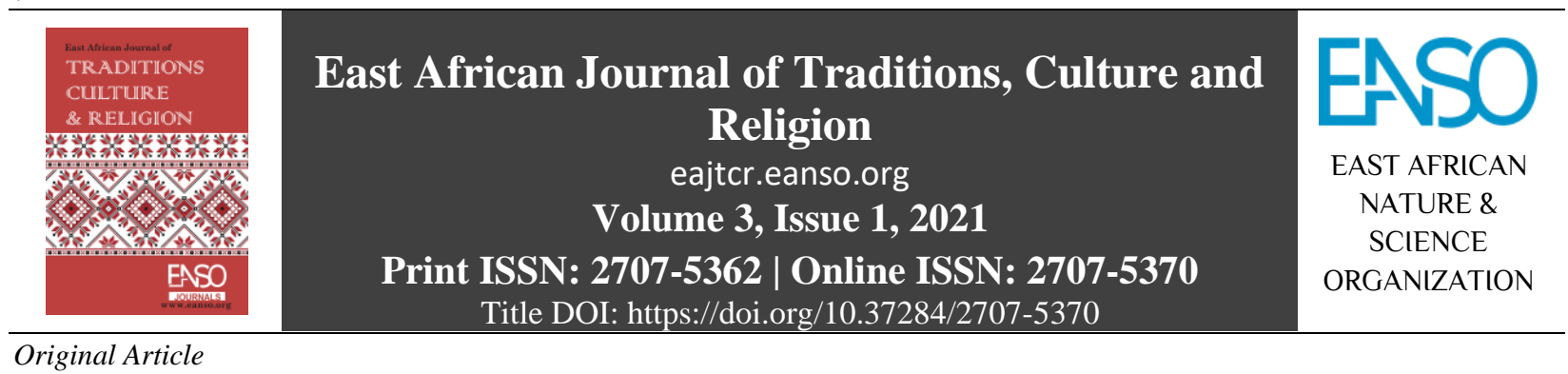

\title{
Christological Contextualization as a Parameter to Strengthen Theology Formulation and Enhance Christian Evangelization in Africa.
}

\author{
Peter Lee Ochieng Oduor, $P h D^{1 *}$ \\ ${ }^{1}$ Africa International University, Nairobi, Kenya \& Nairobi Evangelical Graduate School of Theology. \\ * Author for Correspondence Email: pastoroduorlee@gmail.com.
}

Article DOI: https://doi.org/10.37284/eajtcr.3.2.411

\section{Date Published: ABSTRACT}

14 September 2021

Keywords:

Christology,

Contextualization,

Africanization,

Ethiopianism,

Incarnational,

Indigenizing.
The quest for a contextual African Christianity is one that theological scholarship in Africa should be keen to formulate and construct if the Christian message is to gain the much-needed impact and transformational agenda that will facilitate the process of evangelization of the continent. This is because our theological discourse must be incarnational in theology and methodology. Our study endeavours to submit a contribution in this solemn expedition through an emphasis on the necessity of a contextualized Christology that is cognizant of the African realities and heritage to make the message of Christ be at home to the indigenous African audience. This calls for a paramount understanding of the history of the African people, the African primal religions and most importantly the African culture. The Understanding of these critical issues that together construct the identity of the African will enable the presenter of the Christological message to present the person of Christ that is relevant and addresses the perennial problems that are faced by African communities. This will in the long run make the African to be persuaded to the need to establish a relationship with Christ who is to him a friend or family, Mediator or Ancestor per excellence, Life giver or Healer, and Leader per excellence. These are the realities that Africans would be quick to identify and associate with. To accomplish this, the study observed the significance of the doctrine of Christology in the theological framework; it explored the means with which Christology was administered in Africa in the past. We were able to tackle the subject of Christological Contextualization by observing matters sources and methodology of African Christology and building on the same towards the models that are favourable to Christology in Africa.

\section{APA CITATION}

Oduor, P. L. O. (2021). Christological Contextualization as a Parameter to Strengthen Theology Formulation and Enhance Christian Evangelization in Africa. East African Journal of Traditions, Culture and Religion, 3(1), 58-68. https://doi.org/10.37284/eajtcr.3.2.411

58 | This work is licensed under a Creative Commons Attribution 4.0 International License. 


\section{CHICAGO CITATION}

Oduor, Peter Lee Ochieng. 2021. "Christological Contextualization as a Parameter to Strengthen Theology Formulation and Enhance Christian Evangelization in Africa". East African Journal of Traditions, Culture and Religion 3 (1), 58-68. https://doi.org/10.37284/eajtcr.3.2.411.

\section{HARVARD CITATION}

Oduor, P. L. O. (2021) "Christological Contextualization as a Parameter to Strengthen Theology Formulation and Enhance Christian Evangelization in Africa", East African Journal of Traditions, Culture and Religion, 3(1), pp. 58-68. doi: 10.37284/eajtcr 3.2.411.

\section{IEEE CITATION}

P. L. O. Oduor, "Christological Contextualization as a Parameter to Strengthen Theology Formulation and Enhance Christian Evangelization in Africa”, EAJTCR, vol. 3, no. 1, pp. 58-68 Sep. 2021.

\section{MLA CITATION}

Oduor, Peter Lee Ochieng. "Christological Contextualization as a Parameter to Strengthen Theology Formulation and Enhance Christian Evangelization in Africa." East African Journal of Traditions, Culture and Religion, Vol. 3, no. 1, Sep. 2021, pp. 5868, doi:10.37284/eajtcr.3.2.411.

\section{INTRODUCTION}

The fact of Africa being a critical continent and a key player in the map of world Christianity is a notion that cannot be underestimated or disputed at its core, more so in the century that we are living in. Christianity more than ever is on the rise and we are greatly privileged to be living in Africa at this particular time in history. To our amazement and delight, the future of Christianity in Africa is seen as getting more promising in the future with the trends showing its steady increase. Jenkins (2002, p.2-3) captures this stand as he states that in the previous century there was a shift in the gravity of the Christian world from the North to the South which captures extensively Africa, Asia and Latin America. This is given as evidence of the largest Christian communities on the planet being found in Africa and Latin America. As envisioned in future projections by the accredited World Christian Encyclopedia and documented by Jenkins in Charles L. Harper Jr., John Templeton, (2005, p. 92) that by 2025, Africa and Latin America would be in competition for the title of most Christian continent. About this date, too, another significant milestone should occur, namely that these two continents will together account for half the Christians on the planet. By 2050, only about one-fifth of the world's three billion Christians will be non-Hispanic Whites and Christianity will be primarily a religion of Africa and of the African diaspora in the Americas

If the projections that are submitted are anything to go by then we need to be concerned by the quality of Christians that are being produced in Africa. Africa has been accused of having a Christianity that is numerically strong and qualitatively weak. Mbiti in his work titled 'Some African concepts of Christology” in G. F. Vicedom (ed.), (1972, p. 51) has submitted a diagnosis defining the African Church as "a Church without a theology, without theologians, and without theological concern. According to Mbiti (1970, p. 430), the problem is that "Christianity has Christianized Africa, but Africa has not yet Africanized Christianity". This has generated the debate of quality versus quantity when it comes to the Christianization of the continent. This is the understanding that informed Muchiri $(2009$, p.60) in the common critique that African Christianity is one mile wide and one inch deep. This phrase is a demonstration of the importance of both dimensions in the evangelistic task and should all be accorded a high degree of importance without neglecting either of them. That there is a gross numerical growth; we need to be greatly concerned about how we can transfer this numerical growth to qualitative growth. It is a call to move beyond the realm of evangelism to the realm of discipleship.

The process of discipleship necessitates the involvement of theology as a key tool to ground the church in Africa. The state of affairs as regards to the theological grasp of Christians in Africa has always been said to be wanting in one way or another. Tienou (1982, p.4) correctly presents the situation while quoting Mbiti that the Christians in Africa have a faith but not a theology. It is therefore 
the responsibility of African theologians to develop a theology that is fit for the context of the African continent. That there is a heavy theological presence in Africa is indisputable, yet this theology is largely Western and does so little in addressing the problems raised in the African continent. These sentiments are echoed by Tienou (1982) when he attests to the fact that the theology as we experience in Africa is basically of European origin. This may leave us in a compromise situation in theology as we may find ourselves answering questions that the indigenous may not be asking.

It is in this regard that this study would wish to submit its contribution to the above stated theological malaise by according due attention to the Christological discourse in Africa. This scholarship desires to evaluate the manner in which Christology can be used as a tool to establish a theology that meets the required threshold to be termed as contextual as well as evaluate its role and contribution in the evangelistic mission in the African context. The question that begs to be answered is the possibility of presenting Christology in a manner that can find homage in the cultural understanding and world view of the African audience. The possibility of using this understanding to facilitate the task of mission and outreach in the African context is a matter that this work would also wish to explore. To accomplish this objective this paper will be divided into three major divisions, first, the paper will be keen to answer the question of why the choice of Christology; secondly, we will be interested in the task of contextualizing Christology to our African audience; third will be our interest to submit our recommendation and conclusion on the subject stated above.

\section{Why Christology?}

When it comes to the task of establishing theology that is Christian and anchored on biblical revelation, the subject of Christology can never be underscored or escaped. Christology finds itself in the heart of theology and a critical element in the transmission of the gospel. Kärkkäinen (2003, p. 9) emphasizes that beginning in the biblical period and traveling through two thousand years of winding theological roads, Christian theology has tried to make sense of the person and work of Jesus Christ the founder of
Christianity and the most hotly debated figure of religious history. To distort or undermine the element of Christology is in the long run to water down the impact of the Christian message. (Kärkkäinen, 2003) Expresses this notion in an undisputable means stating that the person of Jesus Christ stands at the centre of Christian faith and theology and for this reason, Christological studies need no prolonged justification in regard to the study of theology and introduction to Christian faith. It is important to acknowledge that 'while no theology can confine itself exclusively to Christology, no Christian theology would be complete without serious reflection on Jesus Christ' in the words of Galvin in his work 'Jesus Christ' in Francis Schussler Fiorenza \& John P. Galvin, (1991, p. 251). The importance of this subject leaves all stakeholders in the practice of theology and disciplines that form branches of theology with the question of how best to transmit this gospel to the diversity of cultural audiences that they address. The question is whether or not there can be a fusion of the institutional theology on the subject of Christology and the popular theology Christology in a measure to speaking the language of potential recipients is a matter of key interest.

The problem that we are faced with is in the quest of establishing a transition from the manner in which Christology was handled in the past to what we need to have. In the past Christology was presented in a manner that showed little or no concern for the cultural context of the recipients. The manner in which Christianity was introduced in black Saharan Africa by the Western missionaries could be said to be part and parcel of European colonialism as has been captured by Nwaogaidu (2016, p.55). Bujo (1992, p.43-44) is keen to point out that the cooperation of the missionaries and the colonizers in wounding the soul of Africa is beyond dispute because of because the missionaries belonged to the same nations as the colonizers and it was unlikely, they would not support the policies of their colonizers. This action led to many instances where the gospel was rejected simply because the Christological presentation was one that was perceived to be ignorant of one cultural context and an extreme bias in one way or another as regards the culture of the presenter. 
The Imperialistic mindset of the missionary enterprise which did not allow for proper integration of the African cultural values to Christianity, brought about alienation from a particular culture and history and herby set Christ against culture as is asserted by (Nwaogaidu, 2016). In Africa, we would be talking of a transfer from a European Christology to a more African contextualized Christology. This is because the missionaries responsible for the presentation of Christology in Africa submitted the same as being integrated within the native European civilization. In relation to this Ratzinger (2007, p. 198-199) regrets that instead of giving Africans God who had come close to us in Christ, which would have integrated and brought to completion all that is precious and great in their own traditions, we gave them the cynicism of a world that is without God in which all that counts is power and profit, a world that destroys moral standards so that corruption and unscrupulous will to power are taken for granted. It is however important to note that it is very unfortunate for us to remain in the realm of blaming the missionaries for the establishment of our theology more than five decades since most African countries attained independence. This exposes our slackness in the task of developing our contextualized theology.

This work would desire to submit its contribution in this development of a contextualized theology with regard to Christology. For purpose of concentration, we would focus largely on the African setting. To carry out this undertaking we would wish to borrow the concept from Andrew Wall that is dubbed the translation principle. We will therefore be keen to evaluate ways and means we can use to approach the Christological subject in a manner that is going to penetrate to the depth of the understanding of the audience that makes the Christological message at home in all cultural groups. Beyond the homing principles is the responsibility of the pilgrim principle that is tasked with the role of seeing the message transform the lives of the community recipients towards the direction of Christ. Before further engagement with the subject, it is important for us to have a definition of the term Christology and thus look at some limitations in handling the subject.

\section{Definition}

It is important for this paper to preserve some time and observe the definition of Christology. This will help us a great deal to understand the scope of our study and make us read from the same script as regard to the understanding of the term. The general understanding is that Christology is the study of Christ as concern his life, works and ministry. There is also the task of capturing the deity of Christ as well as his incarnation. Pam (2012, p.356) has correctly defined the term Christology as that branch of Christian theology that deals with the person of Christ and is not more of the revealed propositions as it is the Christian response to the phenomenon of Jesus. When we come to the study of the person and work of Christ, we are at the very centre of Christian theology because Christians are by definition believers in and followers of Christ and their understanding of Christ must be central and determinative of the very character of the Christian faith as has been stated by Erickson (2000, p. 661-662). These sentiments are echoed by Stinton $(2004, p .1)$ that at the heart of the Christian faith is the person of Jesus Christ and consequently the very core of Christian theology is Christology. Mbiti (1971, p. 190) in the same breath affirms that Christian Theology ought properly to be Christology, for Theology falls or stands on how it understands, translates and interprets Jesus Christ, at a given time, place and the human situation.

\section{Scope of study and Limitations}

The scope of our concentration will be the deity and person of Christ in our quest to bring the message to the context. In acknowledging the wide scope of the subject, this paper would wish to concentrate entirely on library research that will include intensive interaction with books and journals. It is also of great importance at this early stage to identify some limitations of this initiative. That Africa is a vast continent and very populous raises the question of where the researcher begins and how to access these audiences. That there is diversity in our cultures, traditions and customs is a factor that affects the presuppositions we table in the process of scripture interpretation. By virtue of the work being restricted to library research, the researcher is consequently limited to interactions with literature 
or text material as opposed to the interaction with people directly or the context.

\section{CONTEXTUALIZING CHRISTOLOGY TO AFRICAN AUDIENCE}

The concept of Christology has on many occasions been presented in terminologies and expressions that would appear foreign to the African audience. There is no doubt that the influence of the Western thought and the missionary enterprise in general impacted Christological scholarship in Africa in ways thatcan hardly be overestimated as stated by Nwaogaidu (2016, p.55). This has resulted in the Christological message finding little or no relevance to the African world view. It was the missionary presumption of the European value setting for Christian faith that made them have little considerations for any value that originated from African cultural or religious settings in the sentiments of Stinton (2004, p.9). We have seen foreign terminologies used to depict the Christological agenda such as the attributes of the deity of Christ that spring from the philosophical mindset of the western world absent from African mentality and philosophical expressions. Taylor (1963, p.16) has captured this quite elaborately in his deduction of a presentation of Christ that is all out to answer questions that only a white man would be in a position to ask, be steadfast in the solution provision of the needs of westerners, and become the saviour of the world in the world view of the European. All these make the perception of Christianity by many Africans as being a "white man's religion" not engaging in any form of dialogue with the African soul. Stinton (2004, p.16) has also expressed the contrast of this scenario as being literally evident in the Coptic Orthodox Church and the churches that stood for the concept of "Ethiopianism" as the African Independent churches.

There is a dominant need to have a shift from the Christology that is in crisis with the African worldview to one that engages the African mindset. Taylor (1963, p. 7) terms it an urgency in the search of a true meeting place where Christ is conversing with the soul of Africa. Stinton (2004, p. 19 -23) extensively captures the shift in two phases, the first one from the 1950s-1980s known as the Latent Christology that was spearheaded by the All-Africa
Conference of Churches that was constituted in Kampala 1963 intentionally to achieve selfhood for the African church latter meeting in 1969 in Abidjan. They explored the indigenous liturgies and the African expressions of Christian doctrine and firmly declared that "Christ must be the Centre of theology". Their push was largely contributed by factors on the socio-political scenes such as the struggle against colonialism, cultural revolution and the theological renaissance that sweep the continent at this time. The second phase was emergent Christology from the 1980s to the present and was more interested in exploring additional themes in theology by employing genuinely African categories. Christology took centre stage with a transition to worldviews derived from African primal religions such as healer, ancestor or master of initiation.

Bahemuka's article "The hidden Christ in African traditional religion" in Jesse Ndwiga Kanyua Mugambi, Laurenti Magesa ed., (1998, p. 2-13) has identified the problem as being the fact that people's beliefs are part and parcel of the social system in Africa. This is why scholars have argued that Africans are notoriously religious as their social structures nurture, support and mould these religious beliefs since they are at the core of the African existence. In most African societies, there is evidence of the existence of individual and community rituals. The individual rites are designed to take the individual from birth through life to death and joining of the ancestors. All the stages make the individual experience a sense of worth, belonging or appreciation. In the last rite of passage (death) the African graduates to join the communion of ancestors. Dryness (1990, p.43) states that 'the world and life are believed by many African peoples to reflect a fundamental harmony that religion and ritual are meant to preserve and enhance with the essence of religion as directed against threats posed by various forces that cause distress in the living community. Mbiti (1991, p.15) builds further that it is in African religion that gives its followers a sense of security in life and within that religious way of life they know who they are, how to act in different situations and how to solve their problems.

This does not mean that African religion has no weaknesses or false ideas but as far as it goes it has supplied the answers to many of the problems of this 
life even if these may not have been the right answers in every case.Because it provides for them answers and direction in life, people are not willing to abandon it quickly, otherwise, they would feel insecure afterward unless something else gave them an additional or greater sense of security. (Mbiti J. S., 1991) Further alludes that African religion functions more on a communal than an individual basis because beliefs are held by the community therefore it does not matter much whether or not the individual accepts all these beliefs. The ceremonies are performed mainly in or by a group of the family, by relatives, by the whole population of one area or by those engaged in a common occupation. All these serve as awareness on the African mind of the involvement of the divine in all the rituals and thus strengthen the ties of relations between the individual, community and deity. It is therefore imperative for the theologian in Africa to have this understanding to facilitate the efforts of presenting a Christology that speaks to the need of the African context.

To contextualize Christology in Africa the essence of the inculturation process cannot be overemphasized. After the Second Vatican Council, the aim of the church in Africa has been to make the faith about the person of Christ be more at home in the living conditions of the people. This is not a surprise move giving cognizance of the fact that the doctrinal formulation about Jesus Christ was seen as alien to the people and in need of being consolidated in the local culture as captioned by Nwaogaidu (2016, p.45). This is the underlying factor that governs Professor Andrew Walls (2015, p.7) homing principle tasked with the responsibility of making Christology at home in our divergent cultures. The impossibility of separating an individual from his social relationships and thus from his society leads to one unvarying feature in Christian history: the desire to 'indigenize', to live as a Christian and yet as a member of one's own society, to make the church a place to feel at home.

The argument of Wall (2015) is that it is a principle both biblical and historical because God accepts people as they are in their own culture. Walls makes a case for the legitimacy of the indigenizing principle, arguing that a non-believer becomes a Christian in his or her own culture and society in which he/she feels at home which is the essence of the gospel as is captured by Koo (2019, p. 56). Waliggo (1986, p.12) has defined the process as one that is characterized by all seriousness and a spirited attempt to make Christ and his message of salvation through all honesty understood by people of all cultures, locality and time. However, it is important to acknowledge that Walls insists that the indigenizing principle alone is but one side of the essence of the gospel and requires another side, which he calls the pilgrim principle according to the analysis of (Koo, 2019).

Walls (2015, p.8-9) states that not only does God take people as they are: He takes them in order to transform them into what $\mathrm{He}$ wants to be. Along with indigenizing principle, which makes his faith a place to feel at home, the Christian inherits the pilgrim principle, which whispers to him that he has no abiding city and warns him that to be faithful to Christ will put him out of step with his society. Every Christian has dual nationality and has a loyalty to the faith family which links him to those in interest groups opposed to that to which he belongs by nature. It is this dual identity that (Koo, 2019) affirms that makes it possible for us to have a new set of relationships with others in faith thus the pilgrim principle, as the other side of indigenizing principle, leads us to willingly embrace others beyond our natural preference. This strikes a balance to address some elements in African philosophy that are not embracive of people beyond our tribal communities and ethnic orientation.

On this basis it would not be wrong to acknowledge that African Christology inculturation would be the task of Africanizing Christology to the very thought pattern of the African audience. (J N Kanyua Mugambi; Laurenti Magesa ed., (2003, p.17) while capturing Nyamiti's article "African Christologies Today", acknowledges that there are two main types of African theology today and that the first of these is that of inculturation that involves the effort made to incarnate the gospel message in the African cultures on the theological level that is by far the most common and developed theological school in black Africa. With regard to the contemporary African Christologies, Martey (1993, p.78) observe a 'Christological crisis' that has seen Africans at pains to appreciate authentically the person of Jesus Christ. Stinton (2004, p18) explains this 'Christological crisis' as a lack of critical and 
systematic reflection on Jesus Christ by Africans in light of their own cultural inheritance and identity. One of the notable proponents of this ideology is John Mbiti who has been cited as an ardent spokesman for the eminent crisis in textual Christologies as is captured by Martey (1993, p. 78). Kofi Appiah-Kubi in the same breath was quick to lament that the 'missionary dominated churches' in Africa basically accepted conventional, Western academic philosophical teachings about Christ and therefore Jesus Christ seems to be a spiritual intellect or philosophical entity in the missionary churches instead of being a dynamic personal reality in all life situations thus seemingly a general absentee in general crisis situations of the African life as is quoted by (Martey, 1993)

In contrast to the ideological emphasis of Christological crisis, there has also been the advancement of position of Christological confidence as is observed by Stinton (2004, p16) that abounds in the perceptions of Jesus Christ through African eyes as operative among indigenous believers ever since Christianity arrived on the continent. This 'Christological confidence' ideology was advanced from the 1980s to demonstrate a sense of progression in the quest for an independent African understanding of Christ. It is an ideology bent on appreciation of the milestone achieved over the years towards the achievement of a Christology at home to the African audience. A major proponent of this ideology is theologian Charles Nyamiti in his work "Contemporary African Christologies: An Assessment and Practical Suggestion in Rosino Gibellini, (1994, p. 70) asserts that the literature of Christology in Africa has progressed beyond the voicing of the need of an African Christology or even advocacy of methodologies to be employed towards the actual formulation of distinct Christologies in the continent of Africa. This was a reiteration of an earlier establishment that he has identified that Christology was the most developed subject in African theology to date as captured by Stinton (2004, p18). Baur (1994, p. 304) highlighted Christology as being on an elevated platform to the status of being the central theme behind African theological scholarship.

Nyamiti in (J N Kanyua Mugambi; Laurenti Magesa ed., 2003) is captured again as presenting two procedures that spring to the limelight while undertaking African Christology: an attempt to construct African Christology by starting from the biblical teaching about Christ and strive to find from the African cultural situation the relevant Christological themes; and those who take the African cultural background as their point of departure for Christological elaborations. The first paradigm as further explained in ( $\mathrm{J}$ N Kanyua Mugambi; Laurenti Magesa ed., 2003) is an expression of African reality from the scriptures while the second is an expression of Christology from the African reality. Mbiti is a key proponent of the first approach expressed in (G.F. Vicedom (ed.), , 1972) where his discovery of the idea of Christus Victor (miracle worker and risen Lord) that finds particular relevance in that Christ is the conqueror of the evil powers such as spirits, magic, disease and death that are feared by the African and acts as a guarantee of immortality. Hence Mbiti's strong emphasis on the "Christus Victor" theme which speaks of the one who intervenes as Saviour and Redeemer in the life of the African. Therefore, the task in this realm is to seek to evaluate the themes of scripture that are identical to African cultural tradition and there are illustrations of events such as Christ's birth and baptism that identify with initiation rituals among the African communities.

The challenge to the theologians that expresses a degree of limitation to this approach would be the presence of Christological dimensions that have no direct link or resemblance to articles within traditional African religion. Mbiti in (J N Kanyua Mugambi; Laurenti Magesa ed., 2003) is keen to capture the same as involves the Christological elements that have no parallel resemblance but does not in any way serve to dilute their significance, for instance, the doctrine of the last supper. (Kofi Appiah-Kubi and Sergio Torres, eds., (1979, p.814) has a similar approach to Mbiti drawing expressions of Christ as Mediator or Intermediary; Saviour, Redeemer and Power; Liberator; healer. In the second approach, we can identify Christological concepts from the African cultural world view such as the fact that life is composed of various rituals that act as a passage to usher the individual to a new paradigm in life such as death brings the individual to a realm of joining the ancestors and close 
proximity to deity. Therefore, the death of Christ is not an end in itself but of necessity to embrace the new status both as a mediator and ancestor. Nyamiti is a key proponent of this Christological approach and is captured in his expression:

For as Christian and African religions testify, the parent, continues to live even after death, and to have particular interest in his or her offspring. Death does not bring an end to natural ties, but it simply brings the dead to a new kind of existence, closer to God. A new kind of mystical relationship between the ancestor and his children thereby develops. Christianity, for example, has always taught that children have a special obligation to their dead parents through prayers and that parents if they died in God's friendship have special love for their children and can help them by their intercession with God. This belief is widespread in all societies. (Nyamiti, No. 49), 45.

Though this work finds it difficult to identify with (Nyamiti, No. 49) presupposition on the responsibility of Christians to their dead parents we capture his analogous relationship that through Christ's death and resurrection a mystical relationship has been established between him and the rest of humanity. And that the transition from earthly to heavenly life did not destroy Christ's humanity; in spite of the supernatural qualities, he achieved after his resurrection. He remained perfectly human. There is also the challenge in the attempt to fit Christ in the perspective of all the traits of an ancestor to Christ as other understandings the concepts would carry would be extreme. Therefore, it remains appropriately proper to engage the concept within the analogical realm. This demonstrates by all standards the limitations of this approach to match precepts by precepts. It is at this point that our study finds it appropriate to elaborate that the Christological approach employed by
African scholarship with regard to African Christology should, by all means, appreciate the centrality of scripture as a primary source of our Christology.

This is an emphasis of the authority of the Scripture and as is correctly expressed by Nicholls (2003, p. 43) that the Bible has an authority that precedes and transcends our subjective human experiences of it that though the words used to describe that authority such as infallible, inerrant, behind them stands supra cultural verities inherent in the Word of God itself. Therefore, our model of contextualization is one that acknowledges fidelity to the content of scripture and tradition placing the Christian message as supra culture as is captured by Kudzai (2020, p.45) and therefore in the event of a conflict of interest between the scripture and cultural emphasis or position, the scripture takes preeminence. Having emphasized the centrality of the scriptures, we appreciate other sources of our Christological contextualization as our African history that is inclusive of our primal religions and cultures all of which have a direct relation to contemporary socioeconomic and political African narrative as is captured by Stinton (2004, p. 71). This is brought together with the contemporary Christian witness that is birthed from the foundational element of scripture and Christian tradition (Stinton, 2004). This is accurately captured by (Stinton, 2004) in the figure below that this study would wish to borrow for purposes of elaboration and emphasis that the models that the contextualization will advance are such as that identified below of: Life-giver (Healer); Mediator (Ancestor); Loved One (Family or Friend); and Leader (King, Chief or Liberator). These models would be actual realites that Africans would easily identify with and thus facilitate the understanding and relationship of the Africans to the Biblical message of Christ. 


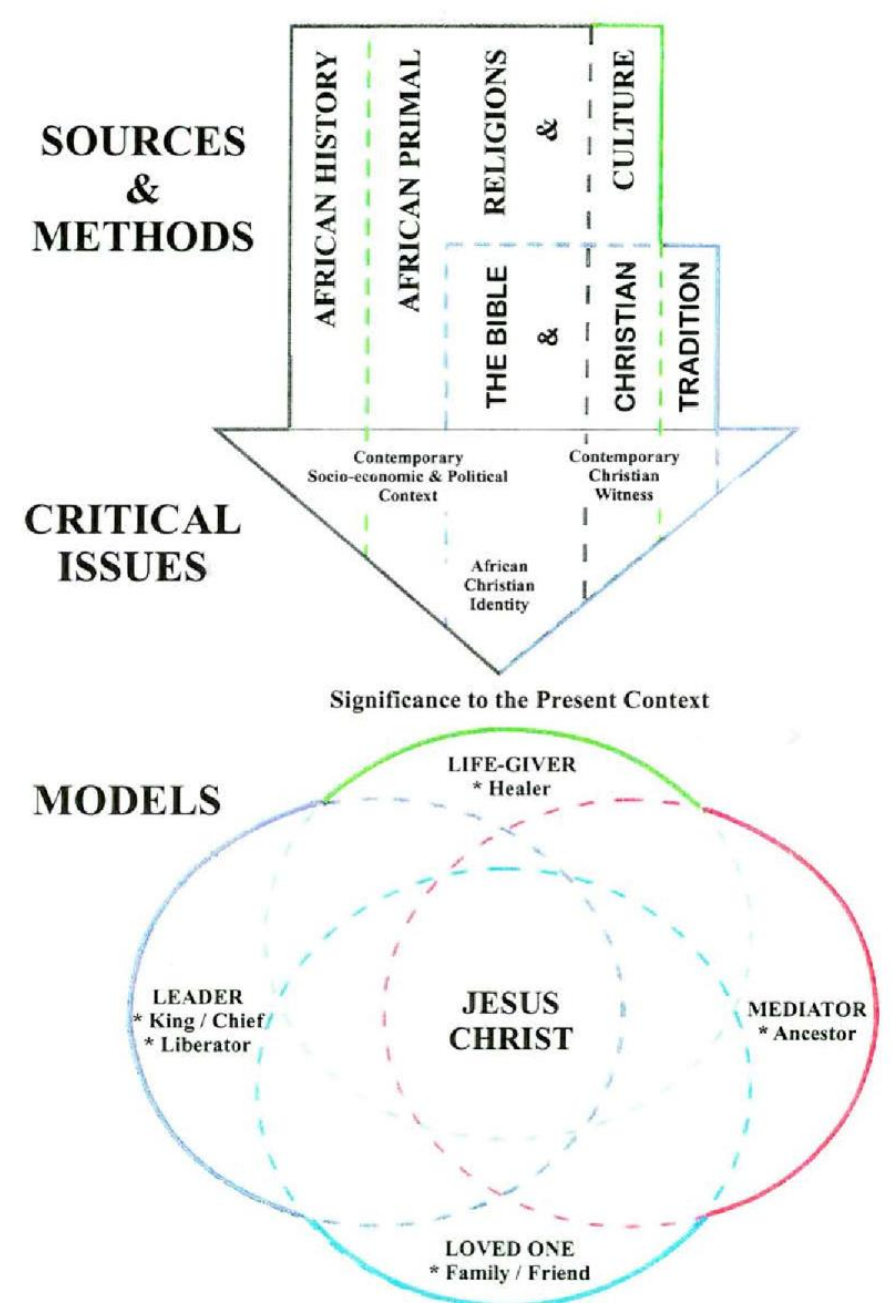

\section{Contribution towards Mission and Outreach}

Having outlined the various approaches and their limitations this study would wish to submit that it is of critical importance for any practicing theologian in Africa to be well versed with the African worldview in order to be in a position to package the gospel message more appropriately in a way it can reach a wider African audience. When Andrew Wall talks of theology being the servant of missions, he says so in regard to a theology that is keen to address the challenges of the audience. As stated in our introduction the homing principle is keen on its demand to have the Christian message receive homage in every cultural setting. This calls for the persons engaged in missions and outreach to be thoroughly informed of the culture of the audience for them to be in a position to present a theology that speaks to their culture. To effectively use the tool of contextualization, the theologian must as well be a student of the culture.

However, caution must be observed so that we do not go overboard and find ourselves bordering syncretism. In our quest to understand the cultural setting our resolve is that whenever there is a contention between culture and scripture, scripture takes pre-eminence. This will help govern the entire process and guard against chances of compromise of being syncretic. However, mission has to be incarnational in theology and methodology, in theology because people from every nation, race and ethnic setting need to hear the gospel, and in methodology because this gospel should be transmitted to them in a way, they are most likely to understand, identify and to relate with. 


\section{RECOMMENDATION AND CONCLUSION}

This study was keenly interested in the evaluation of the manner in which African contextual Christology can be used as a tool to establish a theology that meets the required threshold to be termed as contextual as well as evaluate its role and contribution in the evangelistic mission in the contemporary African context. This study wishes to recommend on the necessity of establishing a theology that is contextual especially with regard to Christology. The curriculum of our institutions of higher learning as regards theology demands a total revision to be in a position to address the needs of the African continent. Integrated into our theological education should be the subjects of contextualization and cultural anthropology that will assist theologians in the task of formulation of theology with an understanding of the culture and world view of the audience. With regard to our specific study, the work would recommend that further studies should be conducted on African Christology especially with regard to the recommended models: Life-giver (Healer); Mediator (Ancestor); Loved One (Family or Friend); and Leader (King, Chief or Liberator) that will strengthen the construction of a CChristology that is at home to the indigenous african audience.

The study also exhorts the professionals involved in scripture translation to be well versed with the cultural context of their audience and not just the language. I am very encouraged by their improvement especially in this direction, specifically when they translated the phrase in John 6: 35, "Then Jesus declared, "I am the bread of life"" in Dholuo that "To Yesu nodwokogi ni 'An e kuon ma ngima" that the translators have captured the context bread to the Luo people would have watered down the significance of the message of Christ in this context but the usage of the word "kuon" that is the staple food in every household and that which is key to the sustenance of life in the Luo community strengthens the understanding of the message to the natives as a presentation of Jesus as that which all humanity cannot exist or survive without. This study believes that these recommendations are important to the productivity of mission practice in the body of Christ within the territory of the continent of Africa.

\section{REFERENCES}

Bujo, B. (1992). African Theology in Its Social Context thanslated by O'Donohue John. Maryknoll, New York: Orbis.

Charles L. Harper Jr., John Templeton. (2005). Spiritual Information: 100 Perspectives on Science and Religion. Philadelphia and London: Templeton Foundation Press.

Dryness, W. A. (1990). Learning about Theology from the Third World. Michigan: Zondervan.

Erickson, M. J. (2000). Christian Theology. Michigan: Grand Rapids: Baker Books.

Francis Schussler Fiorenza \& John P. Galvin. (1991). Systematic Theology: Roman Catholic Perspective 2 vol. Minneapolis: Fortress.

G.F. Vicedom (ed.),. (1972). Christ and the younger churches: Theological contributions from Asia, Africa, and Latin America. London: S.P.C.K.

J N Kanyua Mugambi; Laurenti Magesa ed. (2003). Jesus in African Christianity: experimentation and diversity in African christology. Nairobi, Kenya: Acton Publishers.

Jenkins, P. (2002). The Next Christendom: The coming of global Christianity. Oxford: Oxford University Press.

Jesse Ndwiga Kanyua Mugambi, Laurenti Magesa ed. (1998). Jesus in African Christianity: Experimentation and Diversity in African Christology- African Christianity series/ Coleccion Cuadernos de Arte. Acton.

Kärkkäinen, V.-M. (2003). Christology: A Global Introduction. Grand Rapids MI: Baker Academic.

Kofi Appiah-Kubi and Sergio Torres, eds. (1979). African Theology En Route. Maryknoll, N.Y.: Orbis Books.

Koo, B. O. (2019). Transitioning from an Ethnic to a Multicultural Church: A Transformational Model. Eugene, Or 97401: Wipf and Stock Publishers. 
Kudzai, B. (2020). African Pentecostalism, the Bible, and Cultural Resilience: The Case of the Zimbabwe Assemblies of God Africa, Volume 24 of Bible in Africa Series. University of Bamberg Press.

Martey, E. (1993). African Theology: Inculturation and Liberation. Maryknoll, N.Y.: Orbis Books.

Mbiti, J. (1970). Christianity and traditional religions in Africa. International Review of Mission 59(236), 430.

Mbiti, J. (1971). New Testament Eschatology in an African Background. Oxford: Oxford University Press.

Mbiti, J. S. (1991). Introduction to African Religion, Second Edition. London: Heinemann International Literature and Textbook.

Muchiri, M. N. (2009). Papers on Language and Culture: an African Perspective. Bloomington Indiana: AuthorHouse.

Nicholls, B. J. (2003). Contextualization: A Theology of Gospel and Culture- Volume 3 of Outreach and Identity. Regent College Publishing.

Nwaogaidu, J. C. (2016). Jesus Christ - Truly God and Truly Man-Volume 3 of African theology/ Volume 3 of Afrikanische Theologie. Zurich: LIT Verlag Münster.

Nyamiti, C. (No. 49). African Tradition and the Christian God. Spearhead, 45.

Pam, G. D. (2012). A Compendium of Theology. Jos-Nigeria: Sele Printing and Publishing House.

Ratzinger, J. P. (2007). Jesus of Nazareth: from the baptism in the Jordan to the Transfiguration Part 1(Translated by Walker Adrain J. Great Britain: Bloomsbury.

Rosino Gibellini. (1994). Paths of African Theology. Maryknoll. N.Y: Orbis Books.

Stinton, D. B. (2004). Jesus of Africa: Voices of Contemporary African Christology. Nairobi: Pauline Publications Africa/Daughters of St Paul.
Taylor, J. V. (1963). The Primal Vision: Christian Presence amid African Religion. London: SCM Press.

Tienou, T. (1982). The Theological Task of the Church in Africa. African Christian Press.

Title Christ and the Younger Churches: Theological Contributions from Asia, Africa and Latin America: SPCK theological collections 15 (Issue 15 of Society for Promoting Christian Knowledge). (1972). London: Society for Promoting Christian Knowledge-SPCK.

\section{Waliggo, M. J. (1986). Inculturation: Its Meaning} and Urgency. Nairobi: St. Paul Publications.

Walls, A. F. (2015). Missionary Movement in Christian History: Studies in the Transmission of Faith. Orbis.

68 | This work is licensed under a Creative Commons Attribution 4.0 International License. 